\title{
Surface and subterranean ichthyofauna in the Serra do Ramalho karst area, northeastern Brazil, with updated lists of Brazilian troglobitic and troglophilic fishes
}

\author{
George Mendes Taliaferro Mattox ${ }^{1}$, Maria Elina Bichuette ${ }^{2}$, Sandro Secutti ${ }^{1}$ \& Eleonora Trajano ${ }^{1,3}$ \\ ${ }^{1}$ Departamento de Zoologia, Instituto de Biociências da USP, \\ CP 11461, CEP 05422-970, São Paulo, SP, Brazil, \\ e-mail: gmattox@ib.usp.br, sanoverkill@yahoo.com.br \\ ${ }^{2}$ Departamento de Ecologia e Biologia Evolutiva, \\ Universidade Federal de São Carlos-UFSCar, \\ Via Washington Luis, Km 235, CP 676, CEP 13565-905, São Carlos, SP, Brazil, \\ e-mail:bichuette@uol.com.br \\ ${ }^{3}$ Corresponding author: Eleonora Trajano,e-mail: etrajano@usp.br
}

\begin{abstract}
MATTOX, G.M.T., BICHUETTE, M.E., SECUTTI, S. \& TRAJANO, E. Surface and subterranean ichthyofauna in the Serra do Ramalho karst area, northeastern Brazil, with updated lists of Brazilian troglobitic and troglophilic fishes. Biota Neotrop., 8(4): http://www.biotaneotropica.org.br/v8n4/en/abstract?inventory+bn00 708042008
\end{abstract}

\begin{abstract}
After an ichthyofaunistic survey in several epigean (surface) water bodies of the Serra do Ramalho, southern Bahia, conducted in May 2007, 44 species were recorded; in addition, three non-troglomorphic (normally eyed and pigmented) and two troglomorphic species were recorded only in caves, totaling 49 species of fishes for the area, which represents a little more than one fourth of the total registered in the literature for the entire Rio São Francisco basin. In these caves, which have been studied since 2005, eight non-troglomorphic species were sampled and their presence in both epigean and subterranean habitats, associated to the lack of morphological differences, indicate that they may be either troglophiles (species encompassing individuals able to live and complete their life cycle either in the surface or in the subterranean environment), trogloxenes (individuals regularly found in subterranean habitats, but which must return periodically to the surface in order to complete their life cycle) or even accidental in caves. In addition, two troglomorphic species (with reduced eyes and melanic pigmentation when compared to close epigean relatives), belonging respectively to the genera Rhamdia and Trichomycterus, were recorded exclusively in caves, thus classified as troglobites. Interestingly, no epigean representative of the genus Trichomycterus was collected. The new data are integrated into updated lists of Brazilian troglobitic and troglophilic fishes, based on published data and new records recently confirmed.
\end{abstract}

Keywords: Bahia State, caves, troglobites, troglophiles, freshwater fishes.

MATTOX, G.M.T., BICHUETTE, M.E., SECUTTI, S. \& TRAJANO, E. Ictiofauna epígea e subterrânea na área cárstica da Serra do Ramalho, nordeste brasileiro, com listas de peixes troglóbios e troglófilos no Brasil. Biota Neotrop., 8(4): http://www.biotaneotropica.org.br/v8n4/pt/abstract?inventory+bn00708042008

Resumo: Um levantamento ictiofaunístico em corpos d’água epígeos (superficiais) da Serra do Ramalho, sul da Bahia, realizado em maio de 2007, resultou no registro de 44 espécies; além destas, três espécies com olhos e pigmentação normais (não-troglomórficas) e duas espécies troglóbias foram encontradas apenas em cavernas, perfazendo um total de 49 espécies na Serra do Ramalho, o que representa pouco mais de um quarto do total registrado na literatura em toda a bacia do Rio São Francisco. Nas cavernas desta área, que vêm sendo intensivamente investigadas desde 2005, oito espécies de peixes não-troglomórficos foram registradas. Sua presença tanto no meio epígeo como no subterrâneo, aliada à ausência de diferenciação morfológica, indica que estas últimas podem ser troglófilas (espécies com indivíduos capazes de viver e completar o ciclo de vida tanto no ambiente superficial como no subterrâneo), trogloxenas (espécies com indivíduos encontrados regularmente em cavernas, mas que devem sair periodicamente ao meio epígeo para completar seu ciclo de vida) ou mesmo acidentais em cavernas. Por outro lado, duas espécies troglomórficas (com redução de olhos e pigmentação melânica quando comparadas com aparentados epígeos próximos), pertencentes respectivamente aos gêneros Rhamdia e Trichomycterus, foram encontradas exclusivamente em cavernas, o que justifica sua classificação como troglóbias (espécies exclusivamente subterrâneas). É interessante notar que nenhum representante epígeo do gênero Trichomycterus foi capturado. Os novos dados são integrados em listas atualizadas de peixes troglóbios e troglófilos no Brasil, baseadas tanto em dados publicados como em novos registros confirmados recentemente. Palavras-chave: Bahia, cavernas, troglóbios, troglófilos, peixes de água doce. 


\section{Introduction}

The Rio São Francisco basin is the third largest Neotropical drainage and is enclosed in an area of more than $630.000 \mathrm{~km}^{2}$ (Sato \& Godinho 1999). Its ichthyofauna began to be studied in the late XVIII and early XIX centuries, with descriptions of a few new species from this basin, culminating in the classic work by Lütken (1875) on fishes from Rio das Velhas, one of the main tributaries of the Rio São Francisco (Britski et al. 1984, Britski 2001). In recent times, ichthyological surveys have yielded a little more than 180 fish species occurring in the drainage, most of them belonging to the orders Characiformes and Siluriformes (Britski et al. 1984, Sato \& Godinho 1999, Alves \& Pompeu 2001, Costa 2002). Even though the ichthyofauna of Rio São Francisco has been studied for more than 200 years, new species from this drainage are still being described nowadays and the taxonomy of certain taxa is far from being totally resolved (e.g., Lima \& Britski 2007).

More than 20 species of Brazilian subterranean fishes are known to present the classical troglomorphisms related to the hypogean life, i.e., reduction of eyes and/or pigmentation at least at some degree beyond that observed in their epigean (surface) congeners, indicating a troglobitic (exclusively subterranean) status. In addition, several non-troglomorphic fishes have also been recorded in caves, being either troglophilic (species able to establish self-sustained populations both in epigean and in subterranean habitats), trogloxenic (found in both epigean and subterranean habitats, but each individual must return periodically to the surface in order to complete its life cycle) or accidentals (Bichuette \& Trajano 2003).

Because the primary criterion to classify subterranean organisms into those categories is distributional, the occurrence also in surface habitats precluding the troglobitic status, a first step to determine the troglobitic, troglophilic or other condition for organisms found in hypogean habitats is the comparison with the local epigean fauna. Therefore, an ichthyofaunistic survey in several epigean water bodies was conducted in May 2007. Herein we present the results of ichthyofaunistic surveys in hypogean and epigean water bodies in the Serra do Ramalho karst area and adjacencies, Bahia State.

\section{Study Area}

The Serra do Ramalho karst area is situated in southwestern Bahia State (BA), Middle Rio São Francisco basin (Figure 1). According to Köppen (1948), the climate is defined as tropical dry, "Aw" type, characterized by a dry winter (March to October) and an annual precipitation around $640 \mathrm{~mm}$ (Instituto Nacional de Meteorologia/ INMET, http://www.inmet.gov.br/html/clima/mapas/?mapa=prec). The native vegetation of the region consists of Caatinga (mesophytic and xeromorphic forests), interspersed with Cerrado (a savannah-like vegetation). The Serra do Ramalho is dominated by a plateau formed by carbonatic (limestone) rocks of the Bambuí Group (Auler et al. 2001). This plateau extends for kilometers and forms large cave systems in the region, distributed in two sections, the lower plateau, to the south, and the upper plateau, to the north. The caves focused in this work, Enfurnado Cave (13 $38^{\circ} 45.47^{\prime \prime} \mathrm{S}$ and $\left.44^{\circ} 12^{\prime} 7.11^{\prime \prime} \mathrm{W}\right)$, on the upper plateau, and Água Clara (13 $48^{\prime} 2.83^{\prime \prime} \mathrm{S}$ and $\left.43^{\circ} 57^{\prime} 4.76^{\prime \prime} \mathrm{W}\right)$

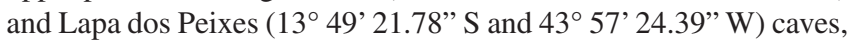
on the lower plateau, are formed basically by river conduits (large in the Enfurnado and Água Clara and small in Lapa dos Peixes). These conduits are subject to accentuated decrease in the water level along the dry seasons, resulting in a strong seasonality in the ecosystems dynamics.

Epigean (surface) localities: Six different epigean localities were sampled for fishes and are numbered below. All collection sites

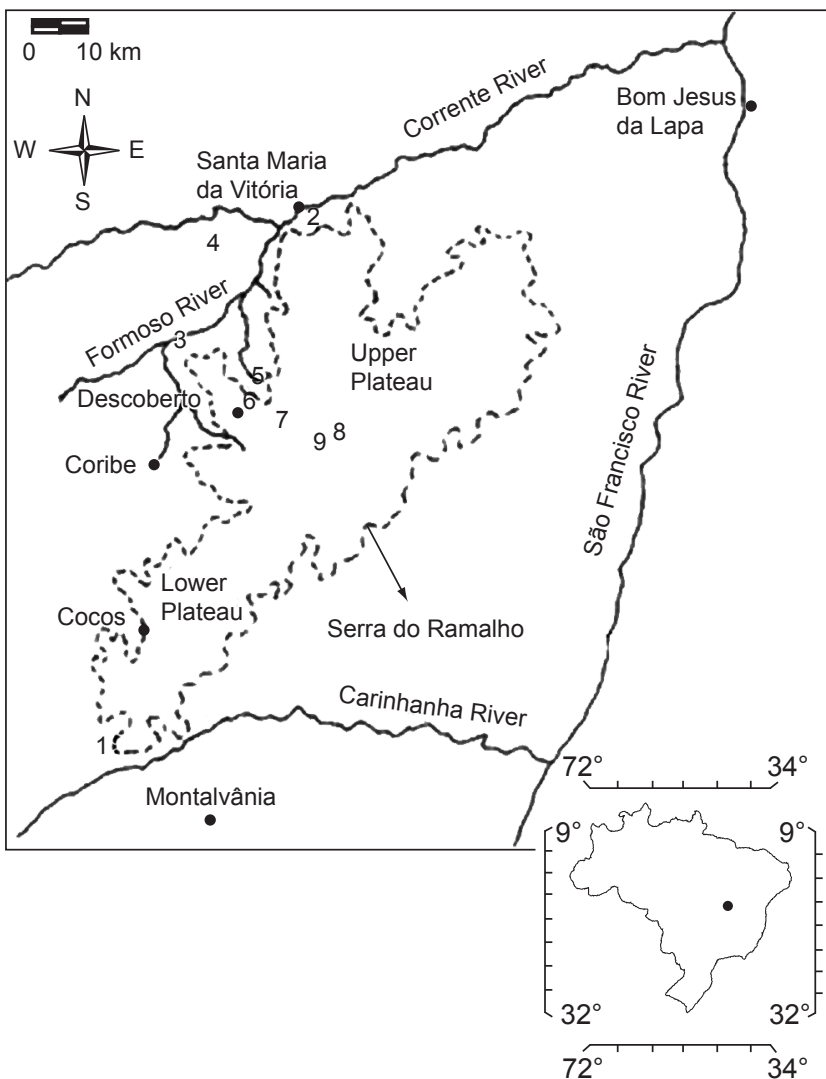

Figure 1. Serra do Ramalho location, Rio São Francisco basin, State of Bahia. The numbers refer to the collecting localities, as listed in the text.

Figura 1. Localização da Serra do Ramalho, bacia do Rio São Francisco, Bahia. os números referem-se aos locais de coleta, como listados no texto.

were sampled during the daytime, and localities 2, 3 and 5 were also sampled during sunset.

1) Rio Itaguari ( $14^{\circ} 15^{\prime} 53.00^{\prime \prime} \mathrm{S}$ and $\left.44^{\circ} 31^{\prime} 28.00^{\prime \prime} \mathrm{W}\right)$, tributary of Rio Carinhanha, affluent of Rio São Francisco. São João de Porto Alegre Village, Town of Cocos, BA. It is a fast flowing, medium sized river, approximately $15 \mathrm{~m}$ wide, with bottom covered by rocks and pebbles and dense vegetation along margins;

2) Rio Correntes (13 $13^{\circ}$ ' $43.40^{\prime \prime} \mathrm{S}$ and $\left.44^{\circ} 06^{\prime} 6.40^{\prime \prime} \mathrm{W}\right)$, affluent of Rio São Francisco. Town of Santa Maria da Vitória, BA. It is a fast flowing river with some calmer areas, approximately $40 \mathrm{~m}$ wide, with bottom covered by sand and mud and dense vegetation along margins, interrupted by some muddy beaches;

3) Rio Formoso ( $13^{\circ} 35^{\prime} 16.00^{\prime \prime} \mathrm{S}$ and $\left.44^{\circ} 18^{\prime} 13.00^{\prime \prime} \mathrm{W}\right)$, tributary of Rio Correntes, affluent of Rio São Francisco. Colônia do Formoso Village between Descoberto and Santa Maria da Vitória, Town of Coribe, BA. It is a fast flowing, medium sized river, approximately $15 \mathrm{~m}$ wide, with bottom covered by mud, sand and pebbles and dense vegetation along margins.

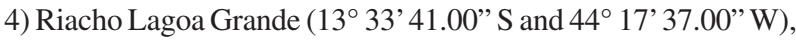
tributary of Rio Correntes, affluent of Rio São Francisco. Town of Coribe, BA. Small winding stream, one or two meters wide, with slow flowing waters and sandy bottom with pebbles, and dense vegetation along margins. The stream is crossed several times by the dirt road between Descoberto and Santa Maria da Vitória, BA;

5) Riacho do Morro Furado (13 $37^{\circ}$ '07.00" $S$ and $44^{\circ} 14^{\prime} 45.00^{\prime \prime} \mathrm{W}$ ), tributary of Rio Volta Pedra, tributary of Rio Correntes, affluent 
of Rio São Francisco. Town of Coribe near Descoberto Village, BA. It is a stream flowing out of Gruta do Morro Furado, three or four meters wide. In its upper reaches, where it slowly flows from the cave, the stream has a low light environment with soft mud bottom and no vegetation. As the stream leaves the cave and light increases, vegetation becomes more abundant along margins, bottom becomes more rocky and water flows faster. In this region, the river also has some slow flowing pools, approximately $2 \mathrm{~m}$ deep, rocky bottom and dense vegetation along margins;

6) Dam in Riacho Verde ( $13^{\circ} 37^{\prime} 7.50^{\prime \prime} \mathrm{S}$ and $\left.44^{\circ} 14^{\prime} 44.90^{\prime \prime} \mathrm{W}\right)$, tributary of Riacho Pitubas, Descoberto Village near Town of Coribe, BA. Lentic environment with muddy bottom and dense vegetation along margins.

Cave localities: Hypogean streams in three caves were sampled:

7) Gruna do Enfurnado Cave $\left(13^{\circ} 38^{\prime} 45.47 " \mathrm{~S}\right.$ and $44^{\circ} 12^{\prime} 7.11^{\prime}$ W), Descoberto Village, Twon of Coribe, located in the upper plateau of Serra do Ramalho. Cave with $7.560 \mathrm{~m}$ of passageways, is one of the largest in the upper plateau. Two streams, one possibly autochthonous, fed by subterranean water, and one allochthonous, cross respectively the distal and the proximal ends of the base-level conduit (the lowest regional erosional level, corresponding generally to a major river that represents the upper limit of the phreatic zone). These streams connect only during very heavy rains, most of the time there are only discontinuous water pools in the intermediate galleries. Connections with the epigean drainage are unknown;

8) Gruna da Água Clara Cave (13 $3^{\circ} 48^{\prime} 2.83^{\prime \prime} \mathrm{S}$ and $43^{\circ} 57^{\prime} 4.76^{\prime}$ 'W), Agrovila 23 Village, Town of Carinhanha, located in the lower plateau of Serra do Ramalho. Cave with $13.880 \mathrm{~m}$ of passageways, is one of the largest in the lower plateau, also formed by two streams, one possibly autochthonous (vadose tributary) and one allochthonous. During the rainy season, a large stream crosses the Gruna da Água Clara and, after a winding open air percours of about $4 \mathrm{~km}$, it enters the main conduit of the Lapa dos Peixes;

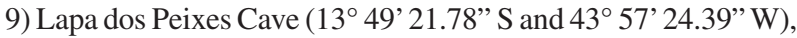
Agrovila 23 Village, Town of Carinhanha, located in the lower plateau of Serra do Ramalho. Cave with $7.020 \mathrm{~m}$ of mapped passageways, with a main conduit crossed by a temporary stream (9) and some upper, mostly dry conduits. Upstream into the upper conduits there is a small permanent vadose tributary $(9 *)$ fed by infiltration water and disappearing into the ground.

\section{Methods}

Collections in epigean sites were carried on using hand nets, trawl seines, cast seines and gill nets of various sizes and small meshes, during one 12 days long field trip, in early May, 2007. Although different localities were not accessed with exactly the same methods, effort was made in order to sample all habitats in each location. Fishes were killed by over-anesthesia in a solution of benzocaine, fixed in formalin $4 \%$ and later transferred to ethanol $70 \%$. Specimens were identified to the species level whenever possible and deposited in the ichthyological collection of the Museu de Zoologia da Universidade de São Paulo, São Paulo state (MZUSP). The relative frequency of the species was calculated in terms of number of individuals of each species in relation to the total collected, expressed in percentage. The species were then classified into four categories, according to their abundance: rare species, less than $1 \%$ of relative abundance; uncommon species, 1-6\% of relative abundance; common species, $6-12 \%$ of relative abundance; very common species, more than $12 \%$ of relative abundance.

Collections in caves were made using hand nets and minnow traps baited with bovine liver. Specimens for taxonomic and anatomical studies were killed and preserved according the procedures described above for epigean fishes.

Table 1. List of species recorded in the Serra do Ramalho. Families are presented in systematic order following Reis et al. (2003), species in alphabetical order within each family. Troglomorphic species are highlighted in bold. Localities: Epigean: 1 - Rio Itaguari; 2 - Rio Correntes; 3 - Rio Formoso; 4 - Riacho Lagoa Grande; 5 - Riacho do Morro Furado; 6 - Dam in Riacho Verde; Caves: 7 - Gruna do Enfurnado; 8 - Gruna da Água Clara; 9 - Lapa dos Peixes.

Tabela 1. Lista das espécies registradas na Serra do Ramalho. Famílias apresentadas em ordem sistemática segundo Reis et al. (2003) e espécies em ordem alfabética em cada família. Espécies troglomórficas destacadas em negrito. Localidades: Epígeas: 1 - Rio Itaguari; 2 - Rio Correntes; 3 - Rio Formoso; 4 - Riacho Lagoa Grande; 5 - Riacho do Morro Furado; 6 - Represa em Riacho Verde; Cavernas: 7 - Gruna do Enfurnado; 8 - Gruna da Água Clara; 9 - Lapa dos Peixes.

\begin{tabular}{|c|c|c|c|c|c|c|c|c|c|}
\hline \multirow[t]{3}{*}{ Táxon } & \multicolumn{9}{|c|}{ Locality } \\
\hline & \multicolumn{6}{|c|}{ Epigean } & \multicolumn{3}{|c|}{ Caves } \\
\hline & 1 & 2 & 3 & 4 & 5 & 6 & 7 & 8 & 9 \\
\hline CLUPEIFORMES & - & - & - & - & - & - & - & - & - \\
\hline Engraulidae & - & - & - & - & - & - & - & - & - \\
\hline Anchoviella vaillanti & - & - & - & $\mathrm{x}$ & - & - & - & - & - \\
\hline CHARACIFORMES & - & - & - & - & - & - & - & - & - \\
\hline Parodontidae & - & - & - & - & - & - & - & - & - \\
\hline Parodon hilarii & - & - & - & - & $\mathrm{x}$ & - & - & - & - \\
\hline Curimatidae & - & - & - & - & - & - & - & - & - \\
\hline Curimatella lepidura & - & - & $\mathrm{X}$ & $\mathrm{x}$ & - & - & - & - & - \\
\hline Steindachnerina elegans & - & - & $\mathrm{X}$ & - & - & - & - & - & - \\
\hline Prochilodontidae & - & - & - & - & - & - & - & - & - \\
\hline Prochilodus costatus & - & - & $\mathrm{X}$ & $\mathrm{x}$ & - & - & - & $\mathrm{X}$ & $\mathrm{x}$ \\
\hline Anostomidae & - & - & - & - & - & - & - & - & - \\
\hline Leporinus sp. & $\mathrm{x}$ & $\mathrm{x}$ & $\mathrm{x}$ & $\mathrm{x}$ & - & - & - & - & - \\
\hline Schizodon knerii & - & - & $\mathrm{X}$ & - & - & - & - & - & - \\
\hline Schizodon sp. & - & - & - & $\mathrm{x}$ & - & - & - & - & - \\
\hline
\end{tabular}




\begin{tabular}{|c|c|c|c|c|c|c|c|c|c|}
\hline \multirow[b]{3}{*}{ Crenuchidae } & \multicolumn{9}{|c|}{ Locality } \\
\hline & \multicolumn{6}{|c|}{ Epigean } & \multicolumn{3}{|c|}{ Caves } \\
\hline & - & - & - & - & - & - & - & - & - \\
\hline Characidium cf. zebra & - & - & $\mathrm{x}$ & - & - & - & - & - & - \\
\hline Characidium sp. & $\mathrm{x}$ & $\mathrm{x}$ & $\mathrm{x}$ & $\mathrm{x}$ & $\mathrm{x}$ & - & - & - & - \\
\hline Characidae & - & - & - & - & - & - & - & - & - \\
\hline Astyanax bimaculatus & - & $\mathrm{x}$ & $\mathrm{x}$ & $\mathrm{x}$ & $\mathrm{x}$ & $\mathrm{x}$ & - & - & $\mathrm{x}$ \\
\hline Astyanax fasciatus & - & - & - & - & - & - & - & - & $\mathrm{x}$ \\
\hline Astyanax lacustris & - & - & $\mathrm{x}$ & - & - & - & - & - & - \\
\hline Astyanax sp. & $\mathrm{x}$ & $\mathrm{x}$ & $\mathrm{x}$ & $\mathrm{x}$ & $\mathrm{x}$ & - & - & - & - \\
\hline Brycon orthotaenia & - & $\mathrm{x}$ & - & - & - & - & - & - & - \\
\hline Bryconamericus stramineus & - & $\mathrm{x}$ & - & - & - & - & - & - & - \\
\hline Bryconops cf. affinis & $\mathrm{x}$ & $\mathrm{x}$ & $\mathrm{x}$ & $\mathrm{x}$ & - & - & - & - & - \\
\hline Hasemania sp. & $\mathrm{x}$ & - & - & - & - & - & - & - & - \\
\hline Hyphessobrycon sp. & - & - & $\mathrm{X}$ & - & - & - & - & - & - \\
\hline Moenkhausia costae & - & - & $\mathrm{x}$ & - & - & - & - & - & - \\
\hline Moenkhausia santaefilomenae & - & - & $\mathrm{x}$ & - & - & - & - & - & - \\
\hline Myleus micans & - & - & $\mathrm{x}$ & - & - & - & - & - & - \\
\hline Myleus sp. & $\mathrm{x}$ & - & - & - & - & - & - & - & - \\
\hline Orthospinus franciscensis & - & - & $\mathrm{x}$ & - & - & - & - & - & - \\
\hline Piabina argentea & - & - & $\mathrm{x}$ & - & - & - & - & - & - \\
\hline Salminus franciscanus & - & $\mathrm{x}$ & $\mathrm{x}$ & - & - & - & - & - & - \\
\hline Serrapinus heterodon & - & - & $\mathrm{x}$ & $\mathrm{x}$ & $\mathrm{x}$ & - & - & - & - \\
\hline Serrapinus sp. & - & $\mathrm{x}$ & $\mathrm{x}$ & - & - & - & - & - & - \\
\hline Tetragonopterus chalceus & - & - & $\mathrm{x}$ & $\mathrm{x}$ & - & - & - & - & - \\
\hline Acestrorhynchidae & - & - & - & - & - & - & - & - & - \\
\hline Acestrorhynchus lacustris & - & - & - & $\mathrm{x}$ & - & - & - & - & - \\
\hline Erythrinidae & - & - & - & - & - & - & - & - & - \\
\hline Hoplias malabaricus & - & - & - & - & - & $\mathrm{x}$ & $\mathrm{x}$ & - & - \\
\hline Hoplias sp. & - & - & $\mathrm{x}$ & - & $\mathrm{x}$ & - & - & - & - \\
\hline SILURIFORMES & - & - & - & - & - & - & - & - & - \\
\hline Trichomycteridae & - & - & - & - & - & - & - & - & - \\
\hline Trychomycterus sp. n. & - & - & - & - & - & - & - & $\mathrm{x}$ & $\mathrm{x}$ \\
\hline Callichthyidae & - & - & - & - & - & - & - & - & - \\
\hline Hoplosternum littorale & - & - & - & - & - & $\mathrm{x}$ & - & - & - \\
\hline Loricariidae & - & - & - & - & - & - & - & - & - \\
\hline Hypostomus cf. francisci & - & - & $\mathrm{x}$ & - & - & - & - & - & - \\
\hline Hypostomus sp. & - & $\mathrm{x}$ & $\mathrm{x}$ & $\mathrm{x}$ & - & - & - & - & - \\
\hline Otocinclus sp. & $\mathrm{x}$ & - & $\mathrm{x}$ & - & - & - & - & - & - \\
\hline Rineloricaria sp. & - & - & $\mathrm{x}$ & - & - & - & - & - & - \\
\hline Pseudopimelodidade & - & - & - & - & - & - & - & - & - \\
\hline Lophiosilurus alexandri & - & - & $\mathrm{x}$ & - & - & - & - & - & - \\
\hline Heptapteridae & - & - & - & - & - & - & - & - & - \\
\hline Pimelodella sp. & - & - & - & - & - & - & - & - & $\mathrm{x}$ \\
\hline Rhamdia enfurnada & - & - & - & - & - & - & $\mathrm{x}$ & - & - \\
\hline Rhamdia sp. & - & - & - & - & - & - & - & - & $\mathrm{x}$ \\
\hline Pimelodidae & - & - & - & - & - & - & - & - & - \\
\hline Pimelodus maculatus & - & - & $\mathrm{x}$ & - & - & - & - & - & - \\
\hline Auchenipteridae & - & - & - & - & - & - & - & - & - \\
\hline Parauchenipterus sp. & - & - & - & $\mathrm{x}$ & - & - & - & - & - \\
\hline GYMNOTIFORMES & - & - & - & - & - & - & - & - & - \\
\hline Sternopygidae & - & - & - & - & - & - & - & - & - \\
\hline Eigenmania cf. trilineata & - & - & $\mathrm{x}$ & - & - & - & - & - & - \\
\hline SYNBRANCHIFORMES & - & - & - & - & - & - & - & - & - \\
\hline Synbranchidae & - & - & - & - & - & - & - & - & - \\
\hline Synbranchus marmoratus & - & - & $\mathrm{x}$ & - & - & - & - & - & - \\
\hline PERCIFORMES & - & - & - & - & - & - & - & - & - \\
\hline Cichlidae & - & - & - & - & - & - & - & - & - \\
\hline Cichlasoma sanctifranciscense & - & - & $\mathrm{x}$ & - & - & - & - & - & - \\
\hline Cichlasoma lepidota & - & - & $\mathrm{x}$ & - & - & - & - & - & - \\
\hline Tilapia rendalii & - & - & - & - & - & $\mathrm{x}$ & - & - & - \\
\hline
\end{tabular}




\section{Results and Discussion}

\section{Epigean ichthyofauna}

The list of species recorded in the Serra do Ramalho is presented in Table 1. A total of 725 specimens of 44 species were sampled at the epigean collection sites. Three species were collected in five different localities (Astyanax bimaculatus, Astyanax sp., and Characidium sp.) and two were collected in four distinct localities (Bryconops cf. affinis and Leporinus sp.). All other species were collected in three or fewer localities. According to the relative abundance, two species were considered very common (Bryconops cf. affinis and Astyanax bimaculatus, 18.2 and $14.9 \%$, respectively), two species were considered common (Astyanax sp. and Characidium sp., $8 \%$ and $6.8 \%$, respectively), 15 species were considered uncommon and the remaining 25 species were considered rare, i.e. occur in less than $1 \%$ of relative abundance. In addition, three non-troglomorphic species were sampled only in caves (Astyanax fasciatus, Rhamdia sp. and Pimelodella sp.), but they are likely to occur in the surface as well.

Among the 49 species herein listed for Serra do Ramalho area, one, Tilapia rendalli, is an exotic species introduced from Africa. All the identified species were previously reported to Rio São Francisco basin, although some of them are not referred to occur in the drainage according to recently published catalogues (Reis et al. 2003, Buckup et al. 2007). This is the case of Bryconops cf. affinis, the most common species sampled in the present work and which is restricted to the coastal streams of the Guyana shield according to Reis et al. (2003), and of Rineloricaria sp., which is not referred as occurring in Rio São Francisco basin in the catalogues (Reis et al. 2003, Buckup et al. 2007). Nevertheless, they both have been previously reported for the drainage by Sato \& Godinho (1999), the former under the name Creatochanes affinis, a junior synonym (Géry 1977). Rineloricaria sp. was also registered by Alves \& Pompeu (2001) in this drainage, while Sato \& Godinho (1999) cited two other species, R. lima and R. steindachneri.

The most diverse family in this survey was Characidae, with 19 registered species representing almost one half of the whole fauna sampled. Besides Characidae, two other families have a large number of species in the Rio São Francisco basin, the siluriform family Loricariidae (Sato \& Godinho 1999, Alves \& Pompeu 2001) with only four species sampled in the present study, and the cyprinodontiform family Rivulidae (Costa 2002), which was not sampled in this survey, although efforts were employed by including temporary ponds in the sampled points.

Fifteen among 49 sampled species, approximatelly $33 \%$ of the diversity accessed, were not identified to the species level. Four other species were not securely identified, receiving "cf." in their identification which indicates that the taxonomic knowledge about these taxa is still not well developed. Lists of species published in recent times also present many taxa identified only to the genus level (e.g., Sato \& Godinho 1999, Alves \& Pompeu 2001). The relative large number of unidentified taxa reflects undescribed or poorly known species. Either way, these taxa reinforce the need for further systematic investigations regarding the fishes from Rio São Francisco basin.

The 47 non-troglomorphic species recorded after a few collections in the Serra do Ramalho represents a little more than one fourth of the total registered in the literature (Britski et al. 1984, Sato \& Godinho 1999, Alves \& Pompeu 2001, Costa 2002) for the whole Rio São Francisco basin. Our collecting localities were all relatively well preserved, even those near Santa Maria da Vitória town, where people use to bath and wash clothes. Therefore, the ichthyofauna in the presently studied area may be considered rich and well representative of the original one, worthy strongly of conservation efforts.

\section{Subterranean ichthyofauna}

Eight species were recorded in caves of Serra do Ramalho (Table 1), including six non-troglomorphic (Prochilodus costatus, Astyanax bimaculatus, Astyanax fasciatus, Hoplias malabaricus, Rhamdia sp. and Pimelodella sp.) and two troglomorphic (Rhamdia enfurnada and Trichomycterus sp. n., as in the list above).

Troglomorphic catfishes have been previously found in two cave systems in the Enfurnado karst area: the heptapterid Rhamdia enfurnada, from Gruna do Enfurnado, its type-locality and only known habitat, at the upper plateau of the Serra do Ramalho (Bichuette \& Trajano 2005), and an undescribed species of Trichomycterus, occurring in at least two caves, the Água Clara Cave and a small vadose tributary inside the Lapa dos Peixes, in the lower plateau. Therefore, we concentrated our studies on these caves. The absence of records of such fishes in surface water bodies supports their status as troglobites.

During the rainy season, a large stream crosses the Gruna da Água Clara and, after a winding open air reach of about $4 \mathrm{~km}$, it enters the main conduit of the Lapa dos Peixes, also crossing it and flowing in the direction of the Rio São Francisco. On these occasions, many fishes from the large epigean Rio São Francisco tributaries go upstream, entering both caves, in a phenomenon locally called "arribada" (which means the act of "going up"). When the dry season comes, the stream partially dries up, leaving isolated pools inside the caves where the fish are trapped; it is a local tradition to capture these fish to eat. After a collection in two of these pools near the main entrance (stream sinkhole) of the Lapa dos Peixes, carried out in September 2007, the following species were sampled: Astyanax bimaculatus (1 specimen), Astyanax fasciatus (10 specimens), Prochilodus costatus (2 specimens), Pimelodella sp. (1 specimen) and Rhamdia sp. (2 specimens). It is noteworthy that no Pimelodella or Rhamdia catfish were captured in the epigean habitats in the Serra do Ramalho, BA.

Troglomorphic Trichomycterus catfish were observed only in a small vadose tributary inside the Lapa dos Peixes, isolated from the main conduit at least during the dry seasons. A few Pimelodella and one Rhamdia small specimens were also repeatedly found in this tributary. These individuals were probably originated from the main conduit populations, which reached the tributary during exceptionally high waters and became stranded when the water returned to the normal level. Although the subadult Pimelodella catfish survived during several months in good physical conditions, probably feeding in the cave, they eventually disappeared from the tributary.

In Gruna do Enfurnado, in addition to the troglobitic Rhamdia enfurnada, some dozens of normally eyed and pigmented individuals of Hoplias group malabaricus were regularly observed. The generally good physical condition of these fish and their permanence in the same sites during months or even years indicate that they are feeding, and possibly also reproducing in the cave, since small specimens were also seen. This, allied to the apparent isolation of the subterranean drainage, indicates that these erythrinids may be troglophilic in the Gruna do Enfurnado.

Updated lists of Brazilian troglobitic and troglophilic fishes are presented respectively in Tables 2 and 3, with data on localities and habitat types (according to Trajano 2001). So far, 24 subterranean troglomorphic fish species have been recorded in Brazil. Among these, six occur in drainages belonging to the Rio São Francisco basin in Minas Gerais and in Bahia States (Table 2): Stygichthys typhlops, Trichomycterus itacarambiensis, Rhamdiopsis sp. from 


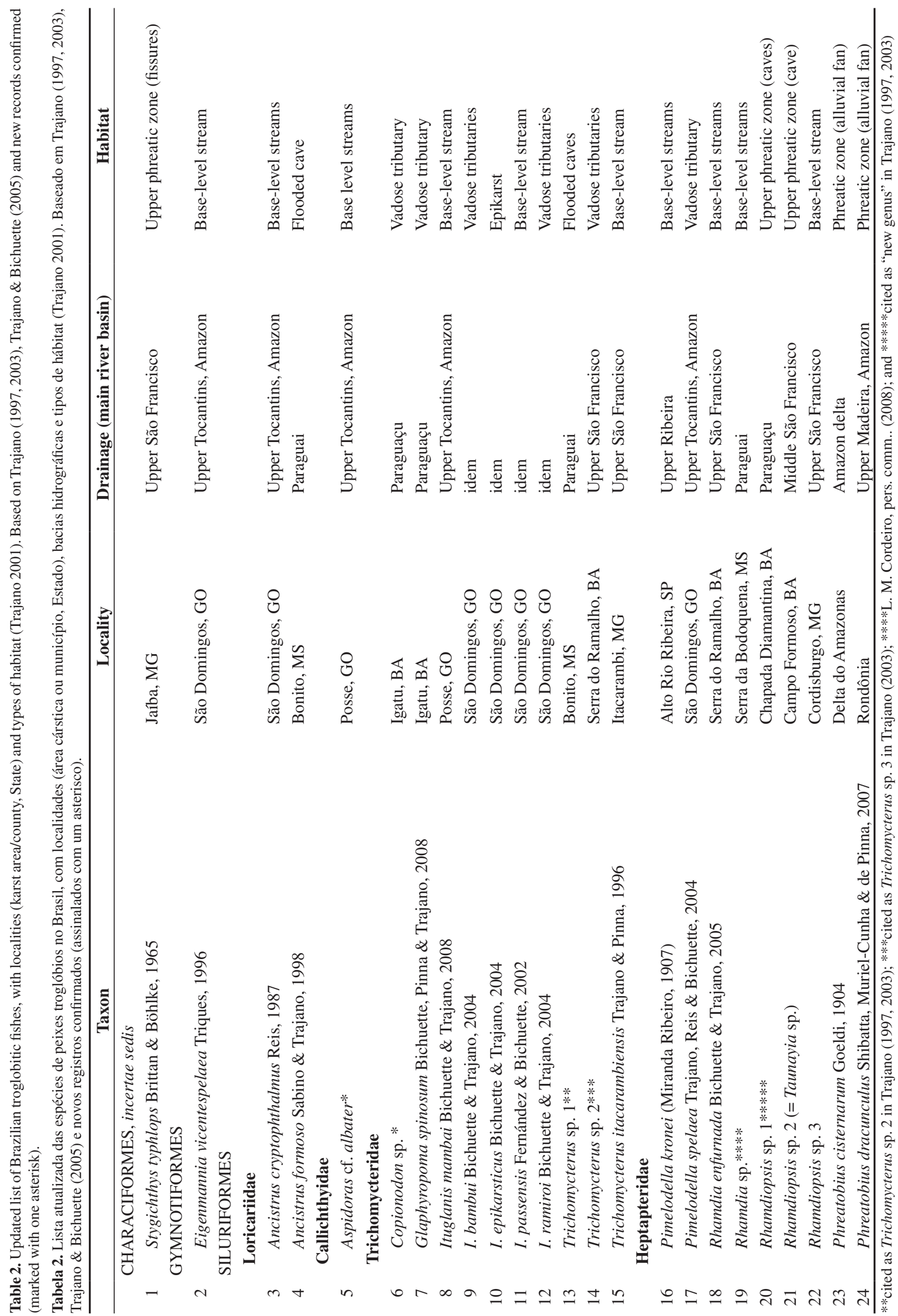


Surface and cave fish in Serra do Ramalho

Table 3. Updated list of Brazilian troglophilic fishes, with localities (karst area/county, State) and types of habitat (Trajano 2001). Based on Bichuette \& Trajano (2003) and new records confirmed (marked with asterisk, locality including cave).

Tabela 3. Lista atualizada das espécies de peixes troglófilos no Brasil, com localidades (área cárstica ou município, Estado), bacias hidrográficas e tipos de hábitat (Trajano 2001). Baseado em Bichuette \& Trajano (2003) e novos registros confirmados (assinalados com um asterisco, localidade incluindo a caverna).

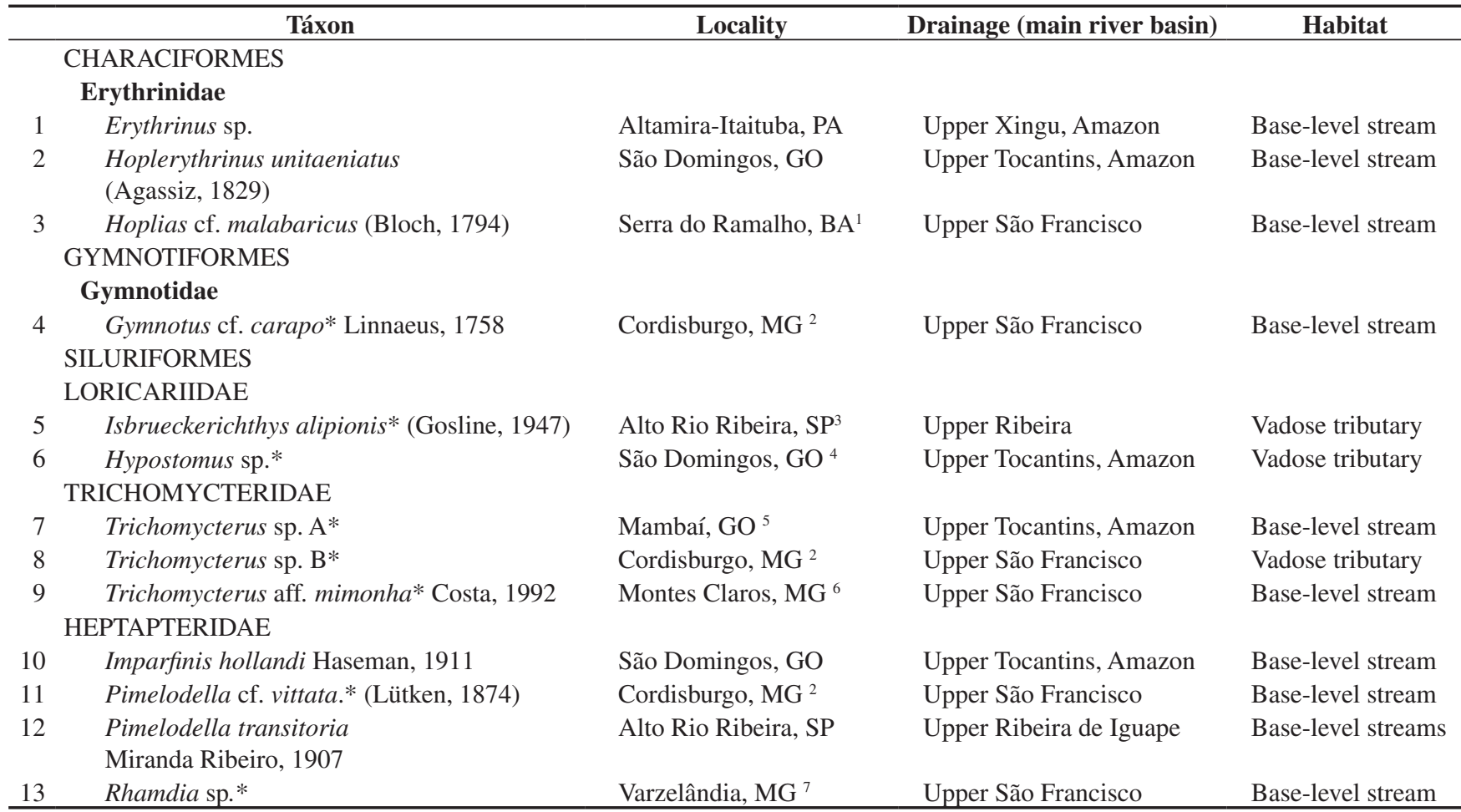

${ }^{1}$ Enfurnado cave; ${ }^{2}$ Morena cave; ${ }^{3}$ Santana cave; ${ }^{4}$ São Bernardo cave; ${ }^{5}$ Penhasco and Nova Esperança caves; ${ }^{6}$ Lapa do Zu cave; and ${ }^{7}$ Zé Avelino cave.

Cordisburgo, Rhamdia enfurnada and Trichomycterus sp. from Serra do Ramalho, in the Upper Rio São Francisco basin, and Rhamdiopsis sp from Campo Formoso, in the Middle Rio São Francisco basin. The Brazilian basin with more troglobitic fish species is the upper Rio Tocantins basin, with nine species (seven in the São Domingos County and two in the Posse County, both in Goiás State). The upper Rio São Francisco, including Serra do Ramalho, is also distinguished by the occurrence of six among the 13 troglophilic fish populations recorded for Brazil (Table 3).

\section{Acknowledgements}

We are most grateful to Osvaldo T. Oyakawa and Janice MurielCunha, from the Museu de Zoologia, who carried out the epigean collections and identifications together with GMTM. Special thanks are also due to the cavers of the Grupo Bambui de Pesquisas Espeleológicas, especially to Ezio Rubbioli, Vitor Moura, Lilia Senna Horta and Augusto Auler, who generously shared information on the cave fauna from the Serra do Ramalho (as from many other Brazilian karst areas) and guided us to these caves, and to the students and biologists who helped with the fieldwork, especially Ana Luiza Feigol Guil and Vanessa Felice. This study was suported by the Fundação de Amparo à Pesquisa do Estado de São Paulo - FAPESP, Projeto Temático \# 2003/00974-5. ET is partially supported by the Conselho Nacional de Desenvolvimento Científico e Tecnológico CNPq (fellowship \# 302174/2004-4). Permission for collections was given by IBAMA (permissions 051-DIFAP/IBAMA, 09/05/2006, and 151/2006-CGFAU).

\section{References}

ALVES, C.B.M. \& POMPEU, P.S. 2001. Peixes do Rio das Velhas: passado e presente. SEGRAC, Belo Horizonte.

AULER, A., RUBBIOLI, E. \& BRANDI, R. 2001. As grandes cavernas do Brasil. Grupo Bambuí de Pesquisas Espeleológicas, Belo Horizonte.

BICHUETTE, M.E. \& TRAJANO, E. 2003. Epigean and subterranean ichthyofauna from São Domingos karst area, Upper Tocantins river basin, Central Brazil. J. Fish Biol. 63(5):1100-1121.

BICHUETTE, M.E. \& TRAJANO, E. 2005. A new cave species of Rhamdia Bleeker, 1858 (Siluriformes: Heptapteridae) from Serra do Ramalho, northeastern Brazil, with notes on ecology and behavior. Neotrop. Ichthyol. 3(4):587-595.

BRITSKI, H.A. 2001. Sobre a obra Velhas-Flodens Fiske [Peixes do Rio das Velhas]. In Peixes do Rio das Velhas: passado e presente (C.B.M. Alves \& P.S. Pompeu, eds.). SEGRAC, Belo Horizonte, p.15-22.

BRITSKI, H.A., SATO, Y. \& ROSA, A.B.S. 1984. Manual de identificação de peixes da região de Três Marias - com chaves de identificação para os peixes da Bacia do São Francisco. CODEVASF, Brasília.

BUCKUP, P.A., MENEZES, N.A. \& GHAZZI, M.S. 2007. Catálogo das espécies de peixes de água doce do Brasil. Museu Nacional, Rio de Janeiro.

COSTA, W.J.E.M. 2002. Peixes anuais brasileiros - diversidade e conservação. Ed. UFPR, Curitiba.

GÉRY, J. 1977. Characoids of the World. T. F. H. Publications, Neptune City, New Jersey.

KÖPPEN, W. 1948. Climatologia. Ed. Fondo Cultural Economica, Mexico City. 
LIMA, F.C.T. \& BRITSKI, H.A. 2007. Salminus franciscanus, a new species from the river São Francisco basin, Brazil (Ostariophysi: Characiformes: Characidae). Neotrop. Ichthyol. 5(3):237-244.

LÜTKEN, C.F. 1875. Velhas-Flodens Fiske. Et bidrag til brasiliens ichthyologi. Efter Professor J. Reinhardts indsamlinger og optegnelser. Kon. Dank. Vidensk. Selsk. Skrift (Raekke) 12:121-253.

REIS, R.E., KULLANDER, S.O. \& FERRARIS Jr., C.J. 2003. Check list of the freshwater fishes of South and Central America. EDIPUCRS, Porto Alegre.

SATO, Y. \& GODINHO, H.P. 1999. Peixes da bacia do Rio São Francisco. In Estudos ecológicos de comunidades de peixes tropicais (R.H. LoweMcConnel, ed.). Edusp, São Paulo, p. 401-413.

TRAJANO, E. 1997. Synopsis of Brazilian troglomorphic fishes. Mém. Biospéol. 24: 119-126.
TRAJANO, E. 2001. Ecology of subterranean fishes: an overview. Environm. Biol. Fish. 62(1-3):133-160.

TRAJANO, E. 2003. Ecology and ethology of subterranean catfishes. In Catfishes. (G. Arratia, B. G. Kapoor, M. Chardon \& R. Diogo, eds.). Science Publishers, Enfield, p. 601-635.

TRAJANO, E. \& BICHUETTE, M.E. 2005. Diversity of subterranean fishes in Brazil. In World Subterranean Biodiversity (J. Gibert, ed.). Proceedings of an International Symposium held on 8-10 December 2004, Villeurbaine, p. 161-163.
Data Received 06/04/08 Revised 06/08/08 Accepted 13/10/08 